\title{
Interfaith Engagement and Orientation Programs
}

\author{
Janett I. Cordoves
}

Professionals working in orientation, transition, and retention (OTR) have expressed apprehension about discussing religion and worldview because it is often considered a personal matter and a subject that can be quickly polarizing. Despite these challenges, there are many benefits to engaging religious and worldview diversity within orientation programs. This Campus Note features stories from the field and highlights how and why worldview and interfaith cooperation can be infused into orientation programs. Indeed, by addressing worldview, an institution can uphold its experiences and values to incoming students.

\section{New Environments}

New encounters in unfamiliar environments, like college campuses, create opportunities for learning, unlearning, and relearning. Orientation programs are a space where students are both excited and anxious about who they will meet, what classes they will select, which groups they will join, and more. It is also a time when students encounter and engage with individuals who are different from them, and for many orientation is the first step into this enriching and new, challenging and supportive, uncomfortable and uniquely amazing world. How might this exciting, anxious, and diverse space support students' holistic development?

For orientation programs to achieve goals of promoting inclusivity and belongingness, OTR staff must intentionally create time for students to connect with their peers, select classes, connect with student organizations, and learn the institution's mission, values, and norms. Orientation programs are excellent at helping students acclimate themselves - and their identities - to unfamiliar environments. Explorations of racial, gender, and sexual orientation dynamics have strengthened the work of orientation programming. To fully support a student holistically, the role of individual worldview must also be taken into account. Recognizing and engaging the religious diversity on campus and in the community-at-large will benefit both incoming students and orientation staff. Leaving out this essential dimension of identity fails to acknowledge students' full selves and also loses a key opportunity to build student skills and awareness around this key element of civic life. The United States is both the most religiously diverse nation in the developed world as well as the most religiously illiterate 
(Prothero, 2007). Engaging religious diversity in some way will assuredly be a part of students' on-campus and professional life journey. Orientation programs have an opportunity to begin a productive educational process around this key civic leadership priority by increasing awareness, deepening knowledge, and positively engaging worldview diversity.

\section{The Value of Religious Diversity in Orientation Programming}

Orientation programs serve as the first meaningful engagement students will have with the campus environment and their new peers. Each entering class is unique, and this incoming class is no exception. In fact, they are the most religiously diverse and politically polarized group our campuses have ever seen (Eagan et al., 2017). How have orientation programs considered responding to this change?

As educators we ask and encourage our students to bring their whole selves to college, but how, when, and where do we capitalize on everyone's differences, specifically around worldview, a "foundational outlook one has on life that helps in making sense of the world" (Mayhew, Rockenbach, Correia, Crandall, Lo, \& Associates, 2016)? Even further, how can we take the charge seriously to engage this diversity productively towards a positive end, a term which Diana Eck calls "religious pluralism" (2003)? As an orientation leader and facilitator, it seems essential, timely, and responsible to consider students' religious, spiritual, and secular identities as they enter college. In the United States, the landscape of religion on college campuses is rapidly changing. Higher education has an opportunity to help students deepen and explore their own worldview, understand other worldviews, and develop a set of civic leadership skills which will enable them to more successfully navigate their community, country, and world.

The Interfaith Diversity Engagement and Attitudes Longitudinal Survey (IDEALS) examines ways in which U.S. undergraduates engage with religious and worldview diversity in college and how that engagement shapes their commitment to religious pluralism. IDEALS shows that $85 \%$ of incoming first-year students have high expectations for campuses to be welcoming environments for diverse worldviews (Rockenbach, Mayhew, Correia-Harker, Dahl, Morin, \& Associates, 2017). However, when asked how welcoming their campuses are toward specific worldviews, students report far lower acceptance rates. What accounts for first-year students' shifting perceptions of their campus climates during their first year?

In the following paragraphs we hope to clarify and define terms, showcase the opportunities orientation programs have in acknowledging and incorporating religious/worldview into programs, and highlight institutions doing just that. It is time orientation, transition, and retention professionals not only ask students to bring their full selves to campus, but that we welcome and engage this form of identity. Students want to actively engage around worldview diversity as soon as they arrive on a campus; we hope to provide a model for how orientation professionals and offices can support that clear need. 


\section{Terms to Know}

Interfaith: This term is best understood by defining each term separately: "inter" and "faith." "Inter" refers to the relationships between people who orient around religion differently. "Faith" is defined as the relationship between an individual and what we commonly understand as a religious or philosophical tradition. Put together, "interfaith" is about how our interactions with those who are different impact the way we relate to our religious and ethical traditions, and how our relationships with our traditions impact our interactions with those who are different from us (Patel, 2017).

Religious Pluralism: The term "pluralism" is understood and defined in a variety of ways. The authors in this article draw understanding from the work of Diana Eck, who argues that diversity is simply the fact of people with different identities interacting with one another (2001). In and of itself, diversity is neither good nor bad. Pluralism, on the other hand, is an achievement. Pluralism has three main parts-respect for all parts of identity, relationships between people and communities who orient around religion differently, and common action for the common good.

Worldview: A guiding life philosophy, which may be based on a religious tradition, spiritual orientation, nonreligious perspective, or some combination of these. (Mayhew et al., 2016). It is the foundational outlook one has on life that helps in making sense of the world.

\section{Engaging Religious \& Worldview Diversity in Orientation Programs}

In an increasingly divisive national and global context, helping students develop pluralistic attitudes that promote bridge-building is all the more important. Interfaith Youth Core (IFYC) is a nonprofit who partners with the higher education sector to serve as a thoughtful and strategic partner in engaging religious literacy and interfaith cooperation. As staff members at IFYC, we work with a network of schools by leading a variety of co-curricular and curricular programs which work to create a world where interfaith cooperation is a social norm. We share the following narratives from actual institutions that are doing meaningful orientation programming addressing issues of religious/worldview diversity.

\section{Campus Examples}

\section{Campus One}

It is common for faith-based institutions to ask, with hesitation, about needing assistance with including an interfaith component into their orientation 
schedule that both reflects their particular values and beliefs as well as welcomes other perspectives. As we continue to engage in these important conversations, it has become clear that colleges and universities are driven to create inclusive and welcoming spaces because of their own values and beliefs, not in spite of them.

For instance, a Catholic university has designed orientation programming with particular goals related to institutional values and beliefs in mind. This programming cultivates students' abilities to think deeply about the values they share with others, introduces them to the diversity of the local community surrounding the campus, and inculcates the importance of service at their institution. Since this school does not have a sole orientation office, much of the organization for their Orientation Week falls to multiple student-related departments, including the Campus Ministry Office.

For years, new students have been asked to participate in service activities during Orientation Week. Campus Ministry saw this as an opportunity to utilize this existing commitment to introduce students to groups with, as one staff organizer put it, "diverse representations [of identity] with diverse offerings [of services]" around their region (K. Heidelberger, interview, April 4, 2018). Campus Ministry chose over 20 local organizations to partner with in this effort; some of these were sacred places or houses of worship, like Hindu temples or Jewish synagogues, and others were community organizations run or supported by religious and non-religious groups, like homeless shelters and forest preserves.

During the beginning of Orientation Week, students signed up for the site they wanted to visit. On the Friday of Orientation Week, all students gathered for an assembly of student speakers. Selected by Campus Ministry staff to represent a cross-section of the campus, these student speakers spoke about their religious/ worldview identity and how it inspired them to serve others. Following the speakers, first-year students were asked to write on a note card what inspires them to serve from their religious or non-religious background and then post it on the wall (later, the notes were distributed to different public spots around campus). After the assembly, students along with faculty or staff members visited their chosen site and learned about the work involved.

The success of the program was immediately obvious. Post-activity surveys showed that the student-led assembly, with its display of speakers from various worldviews, helped students reflect more deeply on their own worldview. In turn, first-year students reported feeling a deeper connection between their belief system and their chosen service project. The project served as a statement about the importance of values on a religiously-affiliated campus, an awareness-raising event for local organizations serving community needs, and a reflective space for entering students. Additionally, a majority of students expressed that the site visit gave them a chance to develop beneficial relationships with campus faculty and staff before setting foot in the classroom. With this feedback, the Campus Ministry staff plans to make this an ongoing part of each orientation and incorporate other values from the Catholic tradition into future activities. 


\section{Campus Two}

In a somewhat different direction, at a private, nonsectarian college, a dedicated orientation committee of staff and faculty from across the institution intentionally included the Dean of Religious and Spiritual Life as they began the planning process. From this perch, the Dean was able to advise on practical issues (like when to provide breaks in the schedule for different religious observances) and shape strategic choices, such as the creation of a "Soulful Sunday" event on the Sunday morning of Orientation Week. This time is focused on exposing students to a variety of worldview perspectives found on their campus. One of the Soulful events is connected to a specific tradition (examples include meditation practices for Hindu students or mezuzah making for Jewish students) and the other encourages broader reflection for all students (examples include a labyrinth walk open to all or a session on how to keep a spiritual journal). These "Soulful Sunday" events are the only events scheduled at this time, an intentional signal to students that these are meaningful opportunities within the orientation schedule. The staff of the Office of Religious and Spiritual Life plan and help lead this portion of the schedule and thus also get to know many of the students personally and develop a greater understanding of their needs as they enter college. These incorporations have engaged students in their own religious, spiritual, and secular journeys as well as exposed them to the diversity of worldviews found on their campus. Highlighting these events at orientation has increased student participation in Religious and Spiritual Life activities throughout the year as students have felt encouraged to explore, engage, and learn more about worldview on their campus. These opportunities have allowed students to gain an appreciation for their worldview and others.

Paired with the programming work during the week itself, the Religious and Spiritual Life Office also offers religious diversity training to student leaders. Led by students from the multifaith group on campus, these trainings are aimed at student leaders and paraprofessionals (first-year mentors, resident assistants, and academic tutors, for instance) who will be interacting with incoming students during orientation week and throughout the school year. The trainings provide data and demographics on the religious diversity of the institution, basic skills for creating a sense of welcome for students from many diverse backgrounds, and practical resources like food/dietary guidelines for different religious groups. As part of the training, student leaders explore case studies which examine the role they play in religious diversity on campus. One case study examined how to build inclusive and welcoming common spaces and hall decorations for students in the residence communities.

The student leaders gave effusive feedback on the trainings and mentioned that these opportunities gave them the chance to broach topics they had seen in their work but had not previously been given a chance to discuss. The success of these trainings was built on the deeply collaborative relationship between the Religious and Spiritual Life Office and the Student Life Department. Both offices saw these programs as the heart of orientation: the ability to support students in orienting themselves and their identity in an unfamiliar environment. 


\section{Takeaways}

- Students arrive on campuses with both a developing understanding of their own worldview and the expectation that there will be a climate to engage with and learn from others of differing backgrounds. Orientation can provide an opportunity for students to reflect upon their and others' worldviews, encourage interaction across worldview categories, and create a space where questions poised are seeking to understand, not attack. Orientation events are excellent opportunities to highlight the values that many different worldviews hold in common. Just as Orientation programming looks different from campus to campus, not all campuses will be able to provide the same type of engagement around issues of worldview diversity. Many private campuses, for instance, might not be able to actively provide completely inclusive programming for all worldviews. Even at those campuses, Orientation programs should seek to welcome and acknowledge all students and, within the context and mission of the institution, suggest campus or community resources that would be helpful.

- Service activities during an Orientation Week offer a chance to showcase community partners and highlight the diversity of the local community. These also provide opportunities for students to interact across differences in order to contribute toward a common good, which is a key catalyst for pluralism.

- Orientation programming which includes interfaith elements can make a significant early impact on conveying an institution's emphasis on certain values, especially when tied directly to the campus' mission.

- Creating specific time to reflect on worldview during orientation programming gives students the chance to connect their worldview identity with their new campus home.

- Proactively helping student leaders prepare to welcome a religiously diverse group of students is a needed and critical aspect of orientation work.

- Cross-departmental partnerships and committees around orientation offer a chance to learn from different areas of campus while supporting overlapping departmental goals.

\section{Things to Consider}

As consideration is given to embedding worldview into orientation programs, understanding an institution's limitations and capabilities is a crucial first step in doing this work well. Below are a set of questions to prompt OTR professionals as they seek to better engage religious and worldview diversity in orientation programs. As you begin to outline your plans, reach out to campus partners, and think through the goals of your orientation program, the questions below will guide you in creating a more inclusive environment of worldview identities, as well as support you in thinking through opportunities to engage this key identity within your offerings. 


\section{Considerations:}

What spaces for spiritual expression and support exist on campus?

Are spaces for spiritual expression and support highlighted throughout orientation? Does the orientation schedule have prayer/meditation spaces labelled?

Does the schedule take into consideration prayer times and religious holidays?

During orientation, is there a time dedicated for students to meet religious, spiritual, secular, and faith-based organizations?

Are the student leaders representative of various worldview perspectives?

Are student leaders aware of the campus' worldview demographics?

Are student leaders trained on how to engage religious/worldview identity?

Do orientation programs convey campus values around the priority of religious/ worldview identity and interfaith cooperation?

\section{References}

Eagan, M. K., Stolzenberg, E. B., Zimmerman, H. B., Aragon, M. C., Whang Sayson, H., \& Rios-Aguilar, C. (2017). The American freshman: National norms fall 2016. Los Angeles, CA: Higher Education Research Institute, UCLA.

Eck, D. L. (2003). Encountering God: A spiritual journey from Bozeman to Banaras. Boston, MA: Beacon Press.

Eck, D. L. (2001). A New Religious America: How a "Christian Country" became the world's most religiously diverse nation. San Francisco, CA: HarperCollins.

Mayhew, M. J., Rockenbach, A. N., Correia, B. P., Crandall, R. E., Lo, M. A., \& Associates. (2016). Emerging interfaith trends: What college students are saying about religion in 2016. Chicago, IL: Interfaith Youth Core.

Patel, E. (2017). Interfaith leadership: A primer. Boston, MA: Beacon Press

Prothero, S. R. (2007). Religious literacy: What every American needs to know--and doesn't. San Francisco, CA: Harper.

Rockenbach, A. N., Mayhew, M. J., Correia-Harker, B. P., Dahl, L., Morin, S., \& Associates. (2017). Navigating pluralism: How students approach religious difference and interfaith engagement in their first year of college. Chicago, IL: Interfaith Youth Core. 